\title{
BENTUK KAPAL PINISI \\ SEBAGAI IDE PENCIPTAAN KARYA SENI LUKIS DENGAN MEDIA TANAH LIAT
}

\author{
Wahyuddin Ridwan dan Sutiyono \\ Universitas Negeri Yogyakarta \\ E-mail: ridwanwahyuddin@gmail.com, sutiyono_63@yahoo.com
}

\begin{abstract}
Abstrak
Tujuan artikel ini untuk mewujudkan bentuk dasar kapal pinisi dalam menerapkan kegiatan melukis dengan menggunakan media tanah liat di dalam pendidikan formal. Penciptaan karya ini menggunakan metode pengembangan. Metode pengembangan penciptaan diperlukan langkahlangkah yang menunjang terciptanya sebuah karya/produk, yaitu: eksplorasi, eksperimentasi, dan pembentukan. Kegiatan eksplorasi dilakukan penjelajahan atau penyelidikan untuk mendapatkan konsep yang akan dijadikan dasar penciptaan. Adapun kegiatan eksperimentasi dimulai dengan pencarian bentuk, teknik. Sedangkan pembentukan yaitu proses perwujudan karya melalui pembuatan model, mendekorasi. Penciptaan karya seni lukis dengan media tanah liat ditemukan bahwa proses ini merupakan upaya dalam pengembangan media seni lukis serta bahan ajar yang bisa diterapkan dalam lingkup pendidikan formal sebagai pedoman dalam pelaksanaan pembelajaran seni budaya khususnya seni rupa yang berbasis kearifan lokal untuk penanaman karakter dan pengembangan kreativitas bagi peserta didik.
\end{abstract}

Kata Kunci: Bentuk kapal pinisi, penciptaan seni lukis, media tanah liat

\section{THE SHAPE OF PINISI SHIP AS A CREATION IDEA OF ART PAINTING WITH CLAY}

\begin{abstract}
The purpose of this article is to realize the basic shape of a Pinisi ship in applying painting activities using clay in formal education. The creation of this work uses a development method. The creation development method requires steps that support the creation of a work, namely: exploration, experiment, and formation. The exploration activities were carried out through exploration or investigation to get the concepts that will be used as the basis of creation. The experiment began with the search of forms, techniques. Meanwhile, the formation activities involving the embodiment of the work through modelling, decorating. From the creation of an art with clay in this study, it was found that it was a development of painting media and teaching materials that could be applied in formal educations as a guideline in the implementation of cultural arts learning, especially art based on local wisdom for the cultivation of character and development of learners' creativity.
\end{abstract}

Keywords: Pinisi ship shape, painting creation, clay media

\section{PENDAHULUAN}

Sumber inspirasi dalam melukis bisa datang kapan saja dan di mana saja, tidak perlu jauh-jauh terkadang malah di lingkungan sekitar yang sering dilihat juga bisa jadi sumber inspirasi. Sebelum ada kapal, perahulah yang sudah dahulu dikenal, adapun bentuk perahu sebanyak tiga yakni Perahu Lesung, Perahu 
Besar tidak Bercadik, dan Perahu Bercadik. Sedangkan kapal layar mempunyai jenis dan bentuk yang sangat beragam, misalnya Kapal Pinisi (kapal layar). Ada dua jenis Kapal Pinisi yaitu Kapal Pinisi Lambo dan Palari. Kapal Pinisi merupakan dari berbagai kelebihan yang dimiliki oleh Kapal Layar, Kapal Pinisi merupakan Kapal tradisional yang mempunyai keistimewaan di banding dengan kapal tradisional yang lain.

Kapal pinisi merupakan kapal layar yang terbuat dari bahan kayu yang di gerakkan dengan tenaga angin. yang istimewa dari kapal ini adalah tiang layar yang ada di kapal tersebut, pada Kapal Layar tradisional lainya tiang layar yang ada hanya berjumlah satu, sedangkan di Kapal Pinisi berjumlah dua buah. Dengan adanya tiang layar (disebut tiang agung) maka tenaga yang di dapat akan lebih besar dari pada yang bertiang satu, dan dengan menggunakan dua tiang layar maka Kapal akan lebih stabil keistimewaan lainya adalah tingkat keseimbanganya (balance) Kapal, pada Kapal Pinisi tingkat keseimbangan Kapal dapat lebih baik karena kontruksi kapal dibikin sedemikian rupa hingga dapat keseimbangan yang baik. Kapal pinisi juga merupakan Kapal Layar tradisional yang mampu melakukan pelayaran dalam jarak yang luas, kekuatan dan kokohnya kapal ini sudah terkenal diantara pelaut. Kapal Pinisi ini bisa di pakai mengankut barang dan juga penumpang, kebanyakan kapal ini dipakai mengankut barang antar pulau. Kapal Pinisi juga dapat dikembangkan menjadi objek karya seni.

Lukisan merupakan benda yang dapat difungsikan sebagai hiasan yang mempunyai pesan tersirat yang bisa dijadikan sebagai media pembelajaran. Dengan menciptakan karya lukis dengan memanfaatkan kapal pinisi sebagai objekmerupakanupayadalammemperkenalkan kambali kearifan lokal Sulawesi selatan. Melihat realitas saat ini, banyaknya generasi yang tidak lagi peduli terhadap budayanya sendiri, Fenomena globalisasi membuat dunia semakin tanpa batas. Perubahan budaya, perkembangan teknologi dan informasi semua berlangsung dalam waktu singkat. Termasuk masyarakat Sulawesi selatan yang mempunyai tradisi membuatan kapal pinisi secara tradisional. Selain ahli dalam membuat kapal phinisi secara tradisional ternyata kapal pinisi yang dibuat mempunyai nilai-nilai kearifan lokal yang mulai dilupakan oleh generasi muda saat ini. Termasuk faktornya adalah masuknya pengaruh globalisasi. Menurut (Zarzar, 2008 \& Berry, 2008) Proses globalisasi menyebabkan homogenitas budaya. Oleh sebab itu penulis tertarik mengangkat kapal pinisi sebagai ide penciptaan karya seni lukis lebih dititik beratkan pada bentuk layarnya, yaitu mempunyai nilai filosofis. Bentuk kapal pinisi tersebut kemudian diekspresikan ke dalam bentuk karya seni lukis dengan menggunakan tanah liat. Perwujudan gagasan ide yang dihasilkan dari pengamatan yang telah dilakukan akan diekspresikan di atas kanvas dengan menggunakan media tanah liat, divisualisasikan dalam bentuk karya dua dimensi.

Dalam proses perwujudan, penulis sekaligus pengkarya menjadikan kapal pinisi sebagai objek dalam seni lukis dengan menggunakan tanah liat diharapkan dapat menjadi media penanaman karakter berbasis budaya lokal sekaligus bahan revitalisasi budaya serta pengembangan kreativitas bagi generasi muda saat ini. Seperti yang ditawarkan oleh Sutiyono dalam jurnalnya yang berjudul Pendidikan Seni Sebagai Basis Pendidikan Karakter Multikulturalis, bahwa Salah satu yang ditawarkan untuk mendukung pendidikan karaktermelalui proses pembelajaranyangdapat dipertanggungjawabkan adalah pendidikan seni. Hal ini disebabkan, dalam pembelajaran seni banyak mempelajari aspek kebudayaan. Anak didik tidak hanya dituntut mahir dalam praktik seni saja, akan tetapi yang lebih penting juga mendalami nilai-nilai kemanusiaan, karena dalam pendidikan seni di antaranya belajar mengolah perasaan. Oleh sebab itu, inilah yang kemudian menjadi dorongan penulis dalam menciptakan ide mengangkat kearifan lokal Sulawesi selatan sebagai sebuah pembelajaran untuk generasi muda. Tujuan utama penulisan ini untuk mewujudkan bentuk dasar kapal pinisi dalam menerapkan kegiatan 
melukis dengan menggunakan media tanah liat di dalam pendidikan formal.

\section{Kajian Teoritik}

\section{A. Kajian Sumber Penciptaan}

Kajian sumber penciptaan, dikaji dari segi bentuk dasar kapal pinisi yang menjadi identitas budaya masyarakat Sulawesi selatan. Hal ini diperlukan untuk mengekspresikan ide gagasan dalam pembuatan objek untuk melahirkan karya. Di samping itu, pengkarya mengambil foto dan gambar kapal pinisi yang sedang berlayar diperoleh dari hasil dokumentasi, studi pustaka, buku, video, katalog, dan internet sebagai acuan berkarya.

Untuk mendekatkan arah pemahaman penciptaan karya ini, maka perlu terlebih dahulu diuraikan tentang ruang lingkup dari kajian sumber penciptaan, diantaranya sebagai berikut:

\section{a. Studi Lapangan / Observasi}

Tahap observasi meliputi aktivitas penjelajahan menggali sumber-sumber ide dengan langkah identifikasi, perenungan, perumusan masalah, penggalian dan mengumpulkanbahanacuan disertaidengan penggambaranjiwauntukmenemukantema dan konsep penciptaan karya. Perancangan yaitu menuangkan ide dan hasil analisis yang dirumuskan, dilanjutkan visualisasi dalam bentuk sketsa alternatif, kemudian ditentukan sketsa terpilih sebagai acuan dalam berkarya untuk proses perwujudan. Observasi yang di lakukan meliputi bentuk dasar kapal pinisi.

\section{b. Studi Pustaka}

Tahap selanjutnya studi pustaka yaitu mencari dan mengumpulkan berbagai macam referensi atau acuan buku, baik berupa tulisan maupun gambar. Studi pustaka ini dilakukan untuk mencari datadata yang berhubungan dengan karya yang akan digarap guna mendapatkan hasil yang lebih maksimal.

\section{B. Landasan Penciptaan}

Penciptaan sebuah karya seni merupakan sebuah rangkaian, proses panjang bagi pengkarya melihat ruang-ruang imajinasi yang akhirnya menjadi potensi bagi pengkarya, dari potensi selanjutnya direfleksikan oleh pengkarya ke dalam wujud sebuah karya seni. Menurut L.H. Chapman (dalam Sahman, 1993:119) bahwa proses kreatif mencipta itu terdiri dari 3 tahapan yaitu:

1. Inception of an idea (upaya menemukan gagasan)

2. Elaboration and refinement (menyempurnakan, mengembangkan, dan menetapkan gagasan awal)

3. Heention in a medium (visualisasi ke dalam medium)

Proses mencari inspirasi adalah upaya seniman menemukan gagasan disinilah seniman memerlukan dorongan yang kuat untuk mencipta, yang muncul pada saat ditemukanya gagasan. Jadi gagasan yang muncul pada tahap awal pada tahap berikunya masih harus disempurnakan menjasi gagasan sedemikian rupa, sehingga nantinya pada kerja penuangannya ke dalam medium dengan muda akan bisa memperoleh bentuk terminalnya. Medium memang harus digunakan, jika kita ingin menuntaskan proses mencipta sampai pada tahapan finalnya. Bisa saja terjadi bahwa sudah pada tahan awal, seniman melibatkan medium dalam kerangka menemukan gagasan, baik awal maupun yang dikembangkan pada tahap berikunya. Intinya adalah medium pada umumnya hanya berkedudukan sebagai sarana bagi seniman untuk mengekspresikan gagasanya.

Untuk itu, Landasan penciptaan karya seni bagi pengkarya yang amat dominan adalah keinginan untuk menciptakan karya seni yang mempunyai nilai keindahan yang tinggi. Di samping itu, juga memiliki makna, pesan dan ekspresi yang ingin disampaikan lewat karya seni lukis dengan ide kapal pinisi dengan menggunakan bahan tanah liat. Pengkarya berharap karya yang akan diciptakan nantinya mampu menjadi sarana komunikasi bagi penikmanya serta menjadi sarana edukasi 
dalam proses pembelajaran di dalam pendidikan formal untuk generasi muda. Maka dalam penciptaan karya seni lukis ini penulis memilih pendekatan bentuk, nilai, dan penerapan dalam pembelajaran seni rupa di sekolah.

\section{Tinjauan Nilai dalam Bentuk Kapal Pinisi}

Kapal pinisi merupakan warisan budaya nenek moyang masyarakat Bugis Makassar yang mempunyai unsur religi yang kaya dengan nilai sebagai sumber pengetahuan kebudayaan. Prosesi pembuatan pinisi di pesisir Kecamatan Bontobahari Kabupaten Bulukumba sangat kental dipengaruhi oleh mitos Sawerigading. Pinisi bagi masyarakat Desa Ara, Tanah Lemo dan Tanah Beru tidak semata-mata merupakan sebuah karya dari sebuah peradaban manusia, namun karya dari manusia beserta kekuatan spiritulisme alam yang tak pernah dapat dipisahkan dan memiliki mekanisme sebab akibat. Alam yang mengajarkan kepada masyarakat ke tiga desa tersebut tentang kepiawaian membuat pinisi. Alkisah diceritakan oleh budayawan setempat bernama Arief Saenong bahwa pada jaman dahulu Sawerigading (putra Raja Luwu) jatuh cinta pada saudara kembarnya yaitu We Tenri Abeng. Karena mereka bersaudara maka cinta tersebut tidak dapat disatukan. Sawerigading disarankan untuk menikah dengan sepupunya yaitu We Cudai Dg. Risompa (Putri Raja CinaWajo) yang memiliki wajah serupa dengan Tenri Abeng, akhirnya Sawerigading pun bersedia. Untuk mengantarkan Sawerigading maka ditebanglah pohon raksasa yang tumbuh di hutan untuk membuat perahu. Ketika pohon tersebut rubuh terjadilah gempa yang selanjutnya pohon tersebut ditelan bumi bersama nenek Sawerigading La Toge Langi (gelar Batara Guru). Beberapa waktu kemudian pohon tersebut muncul kembali di pantai setelah menjadi perahu besar. Berangkatlah Sawerigading ke Cina, dan kemudian menikah dengan We Cudai. Suatu hari Sawerigading pulang ke negerinya, dalam perjalanan perahunya ditimpa badai dan pecah berkepingkeping. Kepingan-kepingan perahu tersebut terdampar di beberapa tempat yaitu kepingan bagian badan di Ara, bagian sotting (linggi) di Tanah Lemo dan bagian layar dan tali temali terdampar di Bira. Mitos inilah yang mendasari keahlian masyarakat di ketiga desa tersebut yaitu masyarakat desa Ara dan Tanah Lemo mahir dalam pembuatan kapal, sedangkan masyarakat Bira mahir dalam berlayar. Sebagian masyarakat desa Ara masih percaya bahwa mereka tidak akan bisa mempunyai kapal karena mereka ditakdirkan sebagai pembuat kapal.

Menurut Amadin Alza (dalam artikel Pemuda maritm 2013) Departemen Kajian Perkapalan bahwa dalam proses pembuatan kapal pinisi, mengandung nilai-nilai kearifan lokal atau nilai-nilai budaya yang dapat dijadikan sebagai acuan dalam kehidupan sehari-hari. Nilai-nilai itu, antara lain kerjasama atau gotong royong, kerja keras, ketelitian, keindahan, dan religius.

Nilai kerjasama tercermin dalam hubungan antara punggawa (kepala tukang atau tukang ahli), para sawi (tukang-tukang lainnya) dan calon-calon sawi serta tenaga-tenaga yang lainnya. Masing-masing mempunyai tugas tersendiri.Tanpa kerjasama yang baik, pinisi tidak dapat terwujud dengan baik.Bahkan, bukan hal yang mustahil perahu tidak pernah terwujud.

Nilai kerja keras tercermin dalam pencarian dan penebangan kayu welengreng atau dewata yang tidak mudah karena tidak setiap tempat ada. Penebangannya pun juga diperlukan kerja keras karena masih menggunakan peralatan tradisional (bukan gergaji mesin). Nilai ini juga tercermin dalam pemotongannya yang tidak boleh berhenti sebelum selesai (terpotong) dan pemasangan atau perakitannya yang membutuhkan kerja keras.Selain itu, nilai ini juga tercermin dalam pendempulan dan peluncuran karena untuk memindahkan perahu dari galangan bukan merupakan hal yang mudah atau ringan, tetapi diperlukan kerja keras yang membutuhkan waktu beberapa hari (sekitar 3 hari atau lebih).

Nilai ketelitian tercermin dalam pemotongan kayu yang harus tepat (mata 
kampak atau gergaji harus tepat pada arah urat kayu).Nilai keindahan dari bentuknya yang dibentuk sedemikian rupa sehingga tampak kuat, gagah, dan indah.

Nilai religius tercermin dalam dua tiang layar utama berdasarkan 2 kalimat syahadat dan tujuah buah layar merupakan jumlah dari surah Al-Fatihah. Kemudian nilai lainya adalah pemotongan pohon yang disertai dengan upacara agar "penunggunya" tidak marah dan pindah ke tempat lain, sehingga segala sesuatu yang tidak diinginkan tidak terjadi. Nilai ini juga tercermin dalam doa ketika perahu akan diluncurkan ke laut ("Bismillahir Rahmanir Rahim Bulu-bulunnako buttaya, patimbonako bosiya, kayunnako mukmamulhakim, laku sareang Nabi Haidir") (Dengan nama Allah Yang Maha Pengasih lagi Penyayang. Kau adalah bulu-bulunya tanah, tumbuh karena hujan, kayu dari kekayuan dari Mukmanul Hakim saya percaya Nabi Haidir untuk menjagamu).

\section{Metode Penciptaan Seni}

Penciptaan karya ini menggunakan metode penelitian dan pengembangan atau dalam bahasa Inggrisnya Research and Development Dalam hal ini Sugiono (2009: 407) mengatakan bahwa metode penelitian dan pengembangan atau dalam bahasa Inggrisnya Research and Development adalah metode penelitian yang digunakan untuk menghasilkan produk tertentu, dan menguji keefektifan produk tersebut. Berdasarkan metode penciptaan di atas diperlukan langkah-langkah yang menunjang terciptanya sebuah karya/produk, diantaranya adalah eksplorasi, eksperimentasi, dan pembentukan. Dalam kegiatan eksplorasi dilakukan penjelajahan atau penyelidikan untuk mendapatkan konsep yang akan dijadikan dasar penciptaan. Adapun kegiatan eksperimentasi dimulai dengan pencarian bentuk, teknik. Sedangkan pembentukan yaitu proses perwujudan karya melalui pembuatan model, mendekorasi. Berkenaan dengan proses penciptaan karya ini, lebih lanjut dapat diuraikan sebagai berikut :

\section{A. Eksplorasi}

Dalam kegiatan eksplorasi penulis melakukan pengamatan atau penyelidikan lapangan untuk menemukan hal-hal yang berkaitan kapal pinisi. Pengamatan atau penyelidikan tersebut dilakukan untuk memperoleh pengetahuan dan informasi tentang hal-hal yang berkaitan dengan sumber inspirasi penciptaan karya seni dan proses penciptaan yang akan dijalani. Kegiatan ini meliputi: Pengamatan secara visual tentang kapal pinisi mencakup media yang akan digunakan untuk merangsang tumbuhnya kreativitas dalam penciptaan karya lukis dengan objek bentuk Kapal Pinisi.

1. Pengumpulan informasi melalui studi pustaka dan studi lapangan untuk mendapatkan pemahaman guna menguatkan gagasan penciptaan dan menguatkan keputusan-keputusan dalam menyusun konsep penciptaan karya.

2. Melakukan analisis terhadap bentuk, fungsi, material, dan teknik yang digunakan dalam pembuatan karya lukis yang terinpirasi dari kapal layar.

3. Mengembangkan media untuk mendapatkan bentuk-bentuk ke dalam lukisan yang kreatif dan inovatif.

\section{B. Eksperimen}

Berkaitan dengan proses penciptaan karya lukis ini, metode eksperimen dilakukan untuk mendapatkan pengalaman baru dari segi bahan yang yang membedakan antara pelukis yang biasanya memakai cat. Kemudian akan diujicobakan menggunakan tanah liat sebagai media dalam pembentukan karya seni lukis.

\section{Pembentukan}

Dalam kegiatan pembentukan karya penulis mengaplikasikan hasil-hasil eksperimen dengan memastikan bahan serta alat yang tepat untuk digunakan pada proses pembuatan karya seni lukis ini. 


\section{a. Bahan dan Alat}

\section{Bahan}

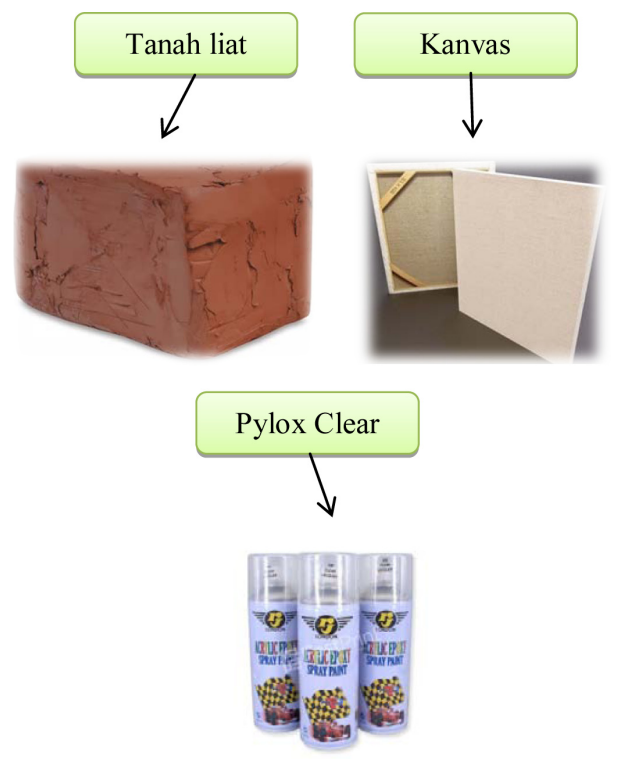

Gambar 2. Bahan dalam Melukis tanah liat

\section{Alat}

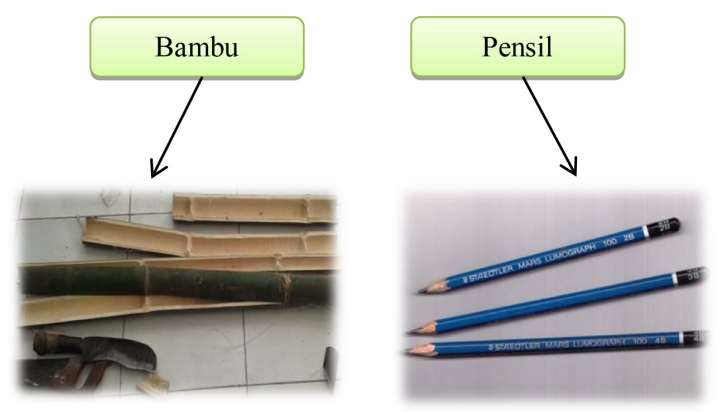

Gambar 3. Alat dalam Melukis Tanah Liat

\section{b. Langkah - langkah Proses Perencanaan \\ Pembuatan}

Adapun proses langkah-langkah perencanaan melukis dengan menggunakan media tanah liat sebagai berikut :

a. Menentukan konsep

b. Mempersiapkan bahan dan peralatan yang dibutuhkan.

c. Proses pengerjaan

1. Membasahi tanah liat sampai merata

2. Tuangkan tanah liat dia atas kertas dan ratakan

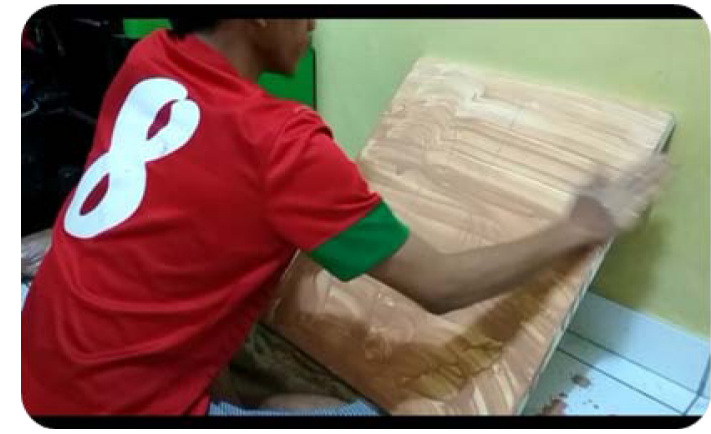

Gambar 4. Proses pemerataan tanah liat di atas kanvas

3. Proses menggambar, sesuai konsep yang diinginkan

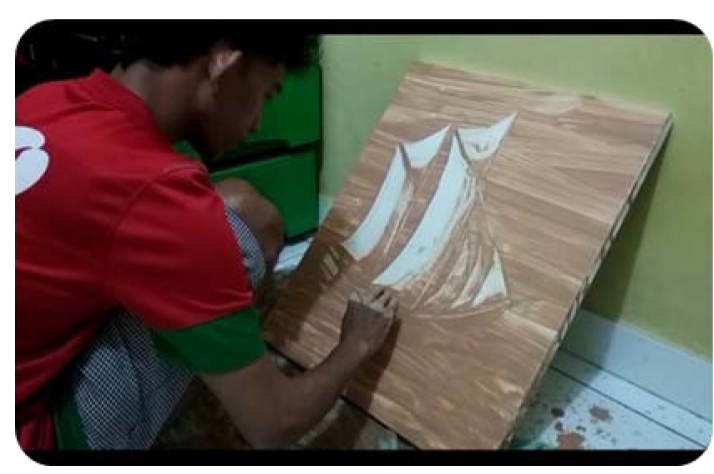

Gambar 5. Proses penggambaran objek lukisan

4. Setalah digambar, kemudian biarkan sampai kering

5. Semprot pylox clear pada gambar yang telah kering, agar mendapatkan hasil yang maksimal dan gambar lebih awet

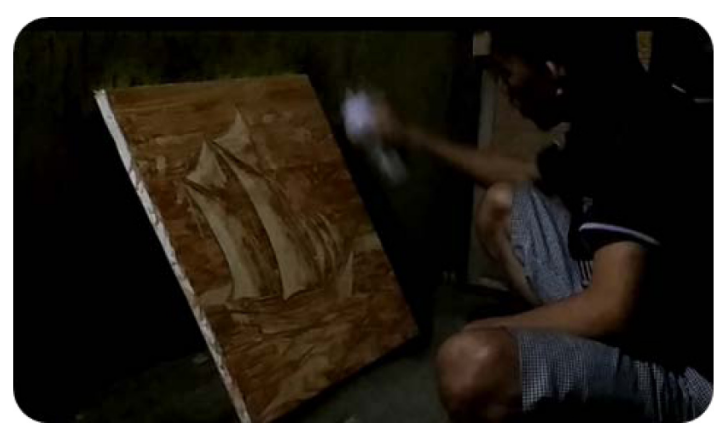

Gambar 6. Proses penyemprotan pylox pada lukisan 


\section{Hasil Lukisan}

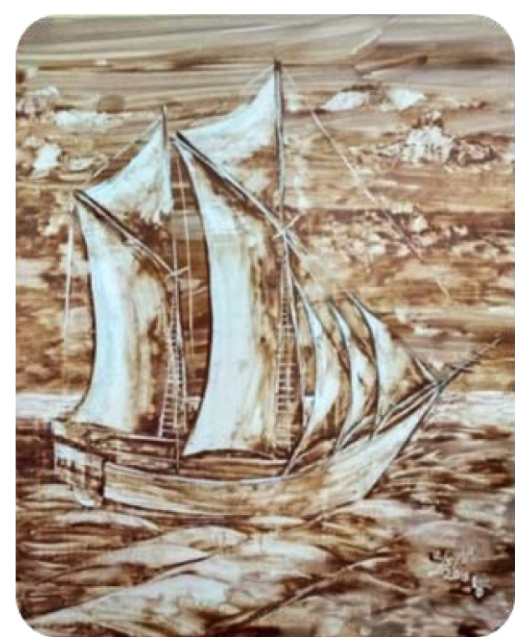

Gambar 7. Hasil Lukisan

\section{PEMBAHASAN}

\section{A. Konsep Penciptaan}

Seorang pengkarya dituntut lebih kreatif dan inovatif untuk menciptakan karya seni. Menciptakan sebuah karya seni seorang pengkarya harus peka terhadap rangsangan yang datang dari dalam maupun dari luar dirinya sendiri. Dalam hal ini sangat memerlukan ide baru dalam melahirkan karya seni lukis.

Berangkat dari tema bentuk kapal pinisi, pengkarya melakukan beberapa langkah untuk mendapatkan karya yang memiliki nilai kreatif dan inovatif. Konsep yang dipakai dalam pembuatan karya ini berupa pemikiran yang mendalam tentang kapal pinisi, baik dari segi bentuk, maupun dari nilai yang terkandung dalam bentuk kapal pinisi itu sendiri.
Sehubungan dengan bentuk karya yang akan diciptakan, sepeti bentuk kapal pinisi yang mempunyai nilai filosofis terhadap kebudayaan Sulwesi selatan. Pengkarya berusaha menvisualisasikan bentuk tersebut ke dalam karya seni lukis dengan menggunakan tanah liat dengan mengutamakan ekspresi melawan ombak.

Kapal pinisi adalah salah satu representasi budaya Sulawesi selatan yang mempunyai nilai kearifan lokal yang harus dilestarikan dan ditanamkan kepada generasi muda masyarakat Sulawesi selatan.

Melihat realitas saat ini, banyaknya generasi yang tidak lagi peduli terhadap budayanya sendiri, Fenomena globalisasi membuat dunia semakin tanpa batas. Perubahan budaya, perkembangan teknologi dan informasi semua berlangsung dalam waktu singkat. Termasuk masyarakat Sulawesi selatan yang mempunyai tradisi membuatan kapal phinisi secara tradisional. Selain ahli dalam membuat kapal phinisi secara tradisional ternyata kapal phinisi yang dibuat mempunyai nilai-nilai kearifan lokal yang mulai dilupakan oleh generasi muda saat ini. Termasuk faktornya adalah masuknya pengaruh globalisasi menurut (Zarzar, 2008 \& Berry, 2008) Proses globalisasi menyebabkan homogenitas budaya. Dominasi budaya Barat berdampak pada budaya lokal. Di seluruh dunia budaya lokal ditekan oleh perkembangan budaya modern mengakibatkan hilangnya keanekaragaman budaya (Sartini, 2004 \& Bhawuk, 2008).
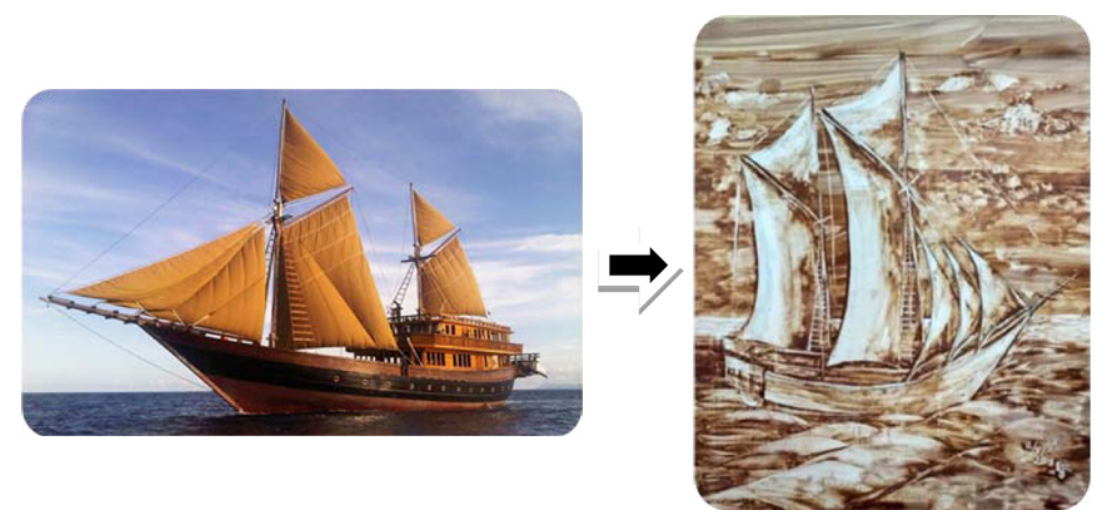

Gambar 4. Desain konsep kapal Pinisi dalam bentuk lukisan tanah liat. 
Nilai-nilai kearifan lokal yang terkandung dalam kapal pinisi diantaranya nilai Identitas atau simbol budaya masyarakat daerah Sulawesi selatan. Kemudian nilai-nilai Religious terdapat pada layar kapal yang berjumlah 7 layar yang bersimbol 7 ayat dari surah al fatihah. Dengan simbol ini dijadikan sebagai falsafah masyarakat bulukumba sebagai doa kesalamatan saat berlayar di lautang, dan nilai Sosial. Melihat kondisi saat ini para generasi muda lebih cepat menangkap pelajaran yang bersifat visual. Oleh sebab itu penulis merancang dengan membuat sebuah karya lukis dengan menggunakan media tanah liat yang bisa diimplementasikan dalam proses pembelajaran seni rupa yang dapat memicu kreativitas peserta didik dan juga sebagai media untuk merevitaslisasi budaya lokal.

\section{B. Penerapan dalam Pembelajaran}

Menurut Susilana dan Riyana (2009:1) Pembelajaran merupakan suatu kegiatan yang melibatkan seseorang dalam upaya memperoleh pengetahuan, keterampilan, dan nilai-nilai positif dengan memanfaatkan berbagai sumber untuk belajar. Untuk mencapai tujuan pendidikan nasional tentu pendidikan seni rupa mempunyai peranan penting. Maka dari itu para pendidik seni harus menerapkan pembejaran yang menarik perhatian siswa agar dapat menerima materi dari guru dengan senang hati. Kaufman (dalam Setyaningrum, 2017: 43) mengemukakan bahwa peranan seni rupa dalam pendidikan sebagai bagian kurikulum sekolah harus dipandang sebagai alat atau media bagi siswa untuk belajar dan tumbuh melalui kegiatan ekspresiestetik. Pendidikan seni mempunyai fungsi yang sangat penting sebagai media dan alat untuk ymencapai tujuan pendidikan, yaitu untuk mengembangkan kesadaran atau kepekaan estetik, mengembangkan daya cipta (kreativitas) dan mengembangkan kesempatan bagi siswa untuk berekspresi. Kemudian ditambahkan Pamadhi (2012:65) bahwa pendidikan seni merupakan pendidikan yang melatih pengamatan indrawi dan mampu mencermati lingkungan sekitar dengan mata, telinga, serta sentuhan secara langsung terhadap alam. Herawati (dalam Setyaningrum, 2017: 43) juga menyatakan bahwa dengan belajar kreatif, akan membantu anak menjadi lebih berhasil guna jika orang tua atau guru tidak bersama mereka, belajar kreatif menciptakan kemungkinan-kemungkinan untuk memecahkan masalah yang tidak mampu diramalkan di masa depan, belajar kreatif dapat mempengaruhi bahkan dapat mengubah karir pribadi serta dapat menunjang kesehatan jiwa dan badan seseorang, belajar kreatif dapat menimbulkan kepuasan dan kesenangan yang besar bagi anak.

Berdasarkan bagunan teori di atas maka penulis dapat menyimpulkan bahwa dengan proses pembelajaran seni rupa khususnya seni lukis dapat mengembangkan kepekaan estetik, mengembangkan daya cipta (kreativitas) mempercepat pemahaman peserta didik. Oleh sebab itu penulis ingin merekomendasikan model pembelajaran seni lukis di dalam pendidikan formal tentang penerapan pembelajaran seni lukis menggunakan bahan tanah liat untuk meningkatkan kreativitas siswa. Selain menumbuhkan kreativitas peserta didik ketika menerapkan pembelajaran seni lukis menggunakan tanah liat dengan memanfaatkan kearifan lokal Sualwesi sealatan yaitu kapal pinisi sebagai objek lukisan. Karena nilainilai kearifan lokal yang terdapat dalam kapal pinisi sebagai sumber pembelajaran bisa menjadi acuan dalam penanamkan karakter moral dalam lingkup dunia pendidikan formal yang berbasis kearifan lokal Sulawesi selatan. Karena Kearifan lokal menurut Primadasa Juniarta, Susilo, dan Mimit Primyastanto, (dalam Agung Leo, 2015) adalah tatanan nilai kehidupan yang diwariskan dari satu generasi ke generasi lain dalam bentuk agama, budaya atau adat istiadat yang biasa diucapkan di alam dalam sistem sosial masyarakat. Kemudaian ditambahkan oleh Rapoport (dalam Dahliani, Sumarno \& Setijanti 2015:157) bahwa Salah satu bentuk kearifan lokal adalah lingkungan binaan sebagai tempat aktivitas manusia dalam merefleksikan ide-idenya. Lingkungan binaan terbentuk oleh dua faktor, faktor utama adalah budaya masyarakat; faktor kedua adalah faktor 
pendukung, yang meliputi iklim, kebutuhan pelindung, bahan bangunan, konstruksi dan teknologi, karakter situs, ekonomi, pertahanan, dan agama. Asumsi inilah yang kemudian menawarkan pengembangan model pembelajaran seni budaya di dalam pendidikan formal berbasis Kearifan Lokalyang merupakan model pembelajaran kontekstual kapal pinisi sebagai sumber belajar. Menurut Nurhadi (dalam Agung Leo, 2015) Pembelajaran kontekstual adalah konsep pembelajaran yang mendorong guru untuk menghubungkan materi yang diajarkan dengan situasi dunia nyata siswa. Sejalan dengan pendangan yang dikeluarkan oleh Hicela Ivon \& Dubravka, 2013 bahwa Sekolah harus memperkenalkan siswa pada warisan budaya artistik sejak usia paling dini, dengan fokus pada penciptaan peluang bagi anak-anak untuk melihat nilai seni warisan sebagai budaya mereka. Murid harus dapat mengambil bagian dalam pengalaman sekolah yang melibatkan warisan dalam karya seni kreatif mereka dalam kerangka mengajar seni, agar mereka tahu bagaimana menghargai, mengenali dan memahami pentingnya warisan budaya di masyarakat di mana mereka tinggal. Kegiatan artistik yang terinspirasi oleh konten warisan menawarkan siswa kesempatan untuk pengalaman yang mendalam, untuk tayangan yang mengilhami "keaktifan", ekspresi spontan, kemungkinan "memasuki" hubungan, dan bereksperimen dan bertukar kekayaan internal mereka dengan orang lain.

Mengingat yang di katankan oleh Anise Baswedan dalam (Inan Kito, You tube chanel 2018) pada acara seminar pendidikan yang dilaksanakan oleh salah satu institusi pendidikan formal di jakarta bahwa faktor utama dalam proyeksi pendidikan abad 21 adalah penenaman karakter. Karakter yang dimaksud adalah karakter moral dan karakter kinerja, kompetensi dan literasi (keterbukaan wawasan).

Berangkat dari pendapat tersebut maka menulis menciptakan ide dengan mengembangkan media pembelajaran berbasis kearifan lokal dengan menciptakan lukisan objek kapal phinisi dengan tujuan sebagai berikut :

1. Mengembangkan karakter moral untuk mencintai serta mempunyai sikap kebanggaan terhadap budayanya sendiri dan ikut serta dalam pelestarian budaya lokal

2. Mengembangkan karakter kinerja siswa dengan memberikan stimulus mengolah kesabaran dan kerajinan serta kerja keras dalam menyelesaikan dan menuntaskan sebuah tanggung jawab (tugas)

3. Mengasah kompetensi kritis siswa. Siswa akan lebih tertarik dengan pembelajaran praktek, secara tidak langsung siswa akan selalu mempertanyakan sesuatu yang mereka belum mengerti, baik dalam mempraktekkan melukis onjek kapal phinisi maupun sejarah kapal pinisi itu sendiri. Yang kedua mengasah kompetensi kreatif siswa, dengan memberikan tugas kepada siswa untuk membuat lukisan objek kapal phinisi secara individu, siswa akan merasakan senang ketika dipertemukan dengan hal-hal yang baru.

4. Keterbukaan wawasan (literasi) yang dimaksud di sini lebih menjurus pada wawasan budaya lokal. Dengan memperaktekkan pembelajaran melukis objek kapal phinisi dengan menggunakan tanah liat selain meningkatkan daya kreativitas siswa secara tidak langsung wawasan siswa akan bertambah khususnya budaya lokal mengetahui nilai-nilai dan fungsi kapal pinisi itu sendiri sebagai bagian dari kearifan lokal Sulawesi selatan dan ikut serta dalam pelestariannya.

Mempraktekkan melukis objek kapal phinisi dengan menggunakan media tanah liat dalam lingkup dunia pendidikan formal akan meningkatkan daya kreasi dan daya apresiasi siswa terhadap budaya lokal Sulawesi selatan khusunya wawasan mengenai kapal phinisi. Upaya ini dapat membina siswa untuk dapat menghayati, menikmati, menghargai serta ikut dalam pelestarian budaya lokal Sulawesi selatan di masa yang akan datang. 
Penulis berinisiatif untuk merevitalisasi kearifan lokal kapal phinis ini sebagai bahan pembelajaran praktek dan pembelajaran apresiasi seni di sekolah dengan tujuan mendalami kembali dan memperkenalkan kearifan lokal serta kekayaan yang dimiliki masyarakat Sulawesi selatan dan meningkatkan kreativitas siswa.

Maka dari itu penulis akan menuangkan ide dalam sebuah karya lukis dengan objek kapal pinishi dengan menggunakan media tanah liat sebagai sarana edukasi, guna agar generasi muda Sulawesi selatan kembali mempelajari kearifan lokal serta ikut dalam menjaga dan melestarikan budaya Sulawesi selatan di masa yang akan datang. Pembuatan lukisan dengan objek kapal phinisi dengan menggunakan media tanah liat dalam pembelajaran seni rupa direkomendasikan dalam bentuk pembelajaran Individu. Dengan pembelajaran melukis objek kapal pinisi dengan media tanah liat bentuk pembelajaran individu dapat mengasah kemampuan daya saing dengan siswa lain dalam menyelesaikan sebuah tugas sehingga karakter kinerja dan kreativitas siswa dapat terbentuk.

\section{KESIMPULAN}

Kapal pinisi sebagai ide dasar penciptaan karya seni lukis dengan menggunakan tanah liat dapat diambil beberapa kesimpulan sebagai berikut :

1. Ide dasar menciptakan karya seni lukis menggunakan tanah liat dengan objek Kapal Pinisi memberikan semangat baru bagi penciptaan seni lukis untuk mengembangkan media dalam melukis lebih lanjut.

2. Ditinjau dari nilai estetik lukisan tersebut menggunakan warna murni tanah liat dan mengutamakan gelap terang dalam menentukan objek dalam lukisan.

3. Melukis dengan menggunakan tanah liat dengan objek kapal pinisi menjadi salah satu upaya dalam pengembangan media seni lukis pada umumnya.

4. Pembuatan karya lukis objek pinisi dengan menggunakan media tanah liat ini dibuat sebagai bahan ajar yang bisa direkomendasikan dan diterapkan dalam lingkup pendidikan formal sebagai pedoman dalam pelaksanaan pembelajaran seni budaya khususnya seni rupa yang berbasis kearifan lokal sebagai penanaman karakter dan pengembangan kreativitas bagi peserta didik.

Dengan terselesainya penulisan ini, dapat memberikan saran maupun masukan dalam pembuatan karya seni lukis dengan menggunakan tanah liat sebagai berikut.

1. Dalam proses pembentukan karya lukis menggunakan tanah liat yang perlu diperhatikan adalah pada saat pemilihan tanah liat. Usahan tanah yang digunakan adalah tanah yang berwarna agak gelap karena hasil yang diinginkan adalah mengutamakan lukisan berkesan gelap terang.

2. Dalam proses pembentukan karya lukis menggunakan tanah liat yang perlu diperhatikan juga adalah menjaga kebersihan lukisan. Karena tanah sifanya cepat kotor pada saat proses berkarya.

\section{DAFTAR PUSTAKA}

Agung Leo, 2015. The Development of Local Wisdom-Based Social Science Learning Model with Bengawan Solo as the Learning Source. Department of Teacher Training and Education Faculty of Surakarta Sebelas Maret University: American International Journal of Social Science.

Berry, J.W. (2008). Globalisation and Acculturation. International Journal of Intercultural Relations No. 32 tahun 2008 hal. 328-336. Elsevier.

Bhawuk, Dharm P.S. (2008). Globalization and Indigenous Cultures: Homogenization Or Differentiation?.International Journal of Intercultural Relations No. 32 tahun 2008 hal. 305-317. Elsevier

Dahliani, Sumarno \& Setijanti 2015. Local Wisdom In Built Environment In Globalization Era. Department of Architecture: International Journal of Education and Research. 
Damajanti I. 2006. Psikologi seni. Program Studi Seni Rupa Fakultas Seni Rupa dan Desain Institute Teknologi Bandung: PT Kiblat Buku Utama.

Hicela Ivon \& Dubravka, 2013. School and the Cultural-Heritage Environment: Pedagogical, Creative and Artistic Aspects. Ceps_Journal.

Koesoema A.D.2015.Pendidikan KarakterUtuh dan Menyeluruh. Cetakan ke-5. Yogyakarta: PT Kanisius.

Nendah Kurniasari \& Christina Yuliaty, dan Nurlaili, 2013. Dimensions of Religious Elements in Making Pinisi. Jakarta : Balai Besar Penelitian Sosial Ekonomi Kelautan dan Perikanan

Sahman Humar, 1993. Mengenali Dunia Seni Rupa tentang Seni, Karya Seni, Aktivitas Kreatif, Apresiasi, Kritik dan Estetika. Semarang :IKIP Semarang Press.

Sartini. (2004). Menggali Kearifan Lokal Nusantara sebagai Kajian Filsafati. Jurnal Filsafat. [Online] Available: http://desaingrafisindonesia. wordpress.com/2009 /02/menggali kearifanlokalnusantara1.pdf. (March 20, 2014)

Setyaningrum, 2017. Ekspresifitas Pembelajaran Seni Lukis dengan Media Cat Air pada Siswa Kelas V Sekolah Dasar Negeri Pekunceng 01. Yogyakarya: Jurnal Universitas Ahmad Dahlan.
Sugiyono. 2009. Metode Penelitian Pendidikan Pendekatan Kuantitatif, Kualitatif, dan R $\& D$. Bandung: Alfabeta.

Susilana \& Riyana. 2009. Media Pembelajaran. Bandung: CV. Wacana Prima

Sutiyono. Pendidikan Seni Sebagai Basis Pendidikan Karakter Multikulturalis. Yogyakarta, jurnal : Fakultas Bahasa dan Seni, Universitas Negeri Yogyakarta.

Pamadhi Hajar, 2012. Pendidikan Seni (Hakikat, Kurikulum Pendidikan Seni dan Pengajaran Seni untuk Anak). Yogyakarta: UNY Press.

Rudi Amir, 2016. Transformasi Budaya Dalam Perspektif Pendidikan Non Formal (Studi pada Masyarakat Pembuat Kapal Phinisi di Kabupaten Bulukumba). Jurnal Penelitian Humano.

Ummysalam, 2017. Buku ajar kurikulum bahan dan media pembelajaran PLS. Yogyakarta: CV Budi Utama

Zarzar, Karina Moraes. (2008). The Question Of Identity In Design. In Karina Moraes Zarzar (Eds.), Understanding Meaningful Environments (Architectural Precedents and the Question of Identity in Creative Design), IOS Press BV, Netherlands.

Sumber Internet :

http://www.pemudamaritim.com/2014/11/ filosofi-pinisi-nilai-budaya-yang-tak.html

Inan Kito. 2018, Seminar Pendidikan 2018. Jakarta: You tube chanel. 